\title{
Soft Magnetic Bulk Glassy Fe-B-Si-Nb Alloys with High Saturation Magnetization above $1.5 \mathrm{~T}$
}

\author{
Akihisa Inoue and Baolong Shen \\ Institute for Materials Research, Tohoku University, Sendai 980-8577, Japan
}

\begin{abstract}
New Fe-based bulk glassy alloys were synthesized in the $\left(\mathrm{Fe}_{0.75} \mathrm{~B}_{0.15} \mathrm{Si}_{0.10}\right)_{100-x} \mathrm{Nb}_{x}$ system by copper mould casting. The maximum diameter of the bulk glassy alloy rod was $0.5 \mathrm{~mm}$ at $1 \mathrm{at} \% \mathrm{Nb}, 1.0 \mathrm{~mm}$ at 2 at $\% \mathrm{Nb}$ and $1.5 \mathrm{~mm}$ at 4 at $\% \mathrm{Nb}$. No glass transition is observed at $0 \mathrm{at} \% \mathrm{Nb}$, but the addition of $\mathrm{Nb}$ causes the appearance of glass transition before crystallization. The glass transition temperature $\left(T_{\mathrm{g}}\right)$ and crystallization temperature $\left(T_{\mathrm{x}}\right)$ of the bulk glassy rods were $815 \mathrm{~K}$ and $858 \mathrm{~K}$, respectively, for the $1 \mathrm{at} \% \mathrm{Nb}$ alloy, and $835 \mathrm{~K}$ and $885 \mathrm{~K}$, respectively, for the $4 \mathrm{at} \% \mathrm{Nb}$ alloy. The reduced glass transition temperature $\left(T_{\mathrm{g}} / T_{\mathrm{l}}\right)$ defined by the ratio of $T_{\mathrm{g}}$ to the liquidus temperature $\left(T_{\mathrm{l}}\right)$ was measured as 0.56 at 1 at $\% \mathrm{Nb}, 0.57$ at 2 at $\% \mathrm{Nb}$ and 0.61 at 4 at $\% \mathrm{Nb}$. There is a tendency for $T_{\mathrm{g}}, \Delta T_{\mathrm{x}}\left(=T_{\mathrm{x}}-T_{\mathrm{g}}\right)$ and $T_{\mathrm{g}} / T_{1}$ to increase with increasing $\mathrm{Nb}$ content. The effect of $\mathrm{Nb}$ addition can be interpreted in the framework of the three component rules for the formation of bulk glassy alloys and the stabilization of supercooled liquid. The Fe-B-Si alloy satisfies the three component rules by the addition of $\mathrm{Nb}$. The bulk glassy alloy rods exhibited good soft magnetic properties, i.e., high saturation magnetization $\left(I_{\mathrm{s}}\right)$ of 1.47 to $1.51 \mathrm{~T}$, low coercive force $\left(H_{\mathrm{c}}\right)$ of 2.9 to $3.7 \mathrm{~A} / \mathrm{m}$ and Curie temperature of 593 to $684 \mathrm{~K}$. The high $I_{\mathrm{s}}$ and low $H_{\mathrm{c}}$, as well as the formation of bulk glassy alloys in the simple alloy system are promising as a new type of soft magnetic bulk alloy.
\end{abstract}

(Received December 5, 2001; Accepted February 25, 2002)

Keywords: iron-based alloy, bulk glassy alloy, copper mould casting, soft magnetic property, high saturation magnetization

\section{Introduction}

A new series of bulk glassy alloys in $\mathrm{Mg}_{-},{ }^{1)} \mathrm{Ln}_{-}{ }^{2)}$ and $\left.\mathrm{Zr}_{-}{ }^{3}\right)$ based systems, which have a large supercooled liquid region before crystallization and a high glass-forming ability were discovered between 1988 and 1990. Since then research on amorphous alloys has been dramatically changed. This is attributed to the fact that these new glassy alloys have critical cooling rates several orders lower than those for other simple metal-based and transition metal-based amorphous alloys. ${ }^{4-7)}$ Subsequently, a number of bulk glassy alloys have been synthesized in various alloy systems, including Fe- ${ }^{8}$ ) $\mathrm{Co}_{-}{ }^{9)} \mathrm{Ni}^{-}{ }^{10)}$ and $\mathrm{Cu}^{1}{ }^{11)}$ based alloys. The lowest critical cooling rate for glass formation is as little as $0.06 \mathrm{~K} / \mathrm{s}^{12}$ ) and the largest thickness for glass formation is as great as $80 \mathrm{~mm}^{.13)}$ In these bulk glassy alloy systems, the development of Febased alloys exhibiting good soft magnetic properties has been of primary importance. Typical Fe-based alloy systems include $\mathrm{Fe}-(\mathrm{Al}, \mathrm{Ga})-\mathrm{P}-\mathrm{B}-\mathrm{C},{ }^{8)} \mathrm{Fe}-(\mathrm{Nb}, \mathrm{Cr}, \mathrm{Mo})-(\mathrm{Al}, \mathrm{Ga})-$ $\left.\mathrm{P}-\mathrm{B}-\mathrm{C},{ }^{14)} \mathrm{Fe}-(\mathrm{Cr}, \mathrm{Mo})-\mathrm{Ga}-\mathrm{P}-\mathrm{B}-\mathrm{C},{ }^{15}\right) \mathrm{Fe}-\mathrm{Co}-\mathrm{Ga}-\mathrm{P}-\mathrm{B}-\mathrm{C},{ }^{16}{ }^{16}$ $\mathrm{Fe}-\mathrm{Ga}-\mathrm{P}-\mathrm{B}-\mathrm{C},{ }^{17)} \mathrm{Fe}-(\mathrm{Zr}, \mathrm{Hf}, \mathrm{Nb})-\mathrm{B},{ }^{18)} \mathrm{Fe}-(\mathrm{Zr}, \mathrm{Hf}, \mathrm{Nb})-\mathrm{Mo}-$ $\mathrm{B}^{19)}$ and $\mathrm{Fe}-(\mathrm{Cr}, \mathrm{Mo})-\mathrm{B}-\mathrm{C} .^{20)}$ The three component rules leading to the formation of bulk glassy alloys through stabilization of supercooled liquid were proposed in 1994 ${ }^{4}$ and they have enabled us to discover a number of bulk glassy alloy systems. It is important to point out that the above-mentioned Fe-based alloys were developed on the basis of the component rules, i.e., (1) a multi-component system consisting of more than three elements, (2) significant differences in atomic size $(>12 \%)$ between the main three elements, and (3) suitable negative heats of mixing between the main elements. $\left.{ }^{5,6}\right)$ It is well known that Fe-based amorphous alloys are formed in the Fe-B-Si system ${ }^{21)}$ and the greatest thickness $(230 \mu \mathrm{m})$ is attained by using the instantaneous stop method of rapidly rotating copper wheel within 1 to 2 seconds. ${ }^{22)}$ However, no glass transition is observed in the $\mathrm{Fe}-\mathrm{B}-\mathrm{Si}$ amorphous alloys over the whole compositional range. We tried to modify the $\mathrm{Fe}-\mathrm{B}-\mathrm{Si}$ alloy system by applying the three component rules, and succeeded in fabricating $\mathrm{Fe}-\mathrm{B}-\mathrm{Si}$ base glassy alloys with a supercooled liquid region before crystallization and a high glass-forming ability. This paper presents data for the compositional range in which glassy alloys are formed in $\mathrm{Fe}-\mathrm{B}-\mathrm{Si}$ base system, and the thermal stability and magnetic properties of the resulting Fe-based bulk glassy alloys.

\section{Experimental Procedure}

Multi-component Fe-based alloys with compositions of $\mathrm{Fe}_{75} \mathrm{~B}_{15} \mathrm{Si}_{10}, \quad\left(\mathrm{Fe}_{0.75} \mathrm{~B}_{0.15} \mathrm{Si}_{0.10}\right)_{100-x} \mathrm{Nb}_{x}$ and $\left(\mathrm{Fe}_{0.775^{-}}\right.$ $\left.\mathrm{B}_{0.125} \mathrm{~S}_{0.10}\right)_{100-x} \mathrm{Nb}_{x}(x=1$ to 4 at $\%)$ were examined in the present study because the largest ribbon thickness of amorphous alloys in the $\mathrm{Fe}-\mathrm{B}-\mathrm{Si}$ system was obtained for the metalloid composition of 15 at $\% \mathrm{~B}$ and 10 at $\% \mathrm{Si}^{22}$ ) The alloy components represent nominal atomic percentages. Their alloy ingots were produced from pure $\mathrm{Fe}, \mathrm{Nb}, \mathrm{Si}$ and $\mathrm{B}$ by arc melting in an argon atmosphere. Bulk samples in a rod form, with diameters of 1 to $3 \mathrm{~mm}$ and a length of $50 \mathrm{~mm}$, were produced by copper mould casting. Ribbon samples with a cross section of $0.02 \times 1 \mathrm{~mm}^{2}$ were also prepared by melt spinning. The glassy phase was identified by X-ray diffraction and the absence of a crystalline phase on a micrometer scale was confirmed by optical microscopy. Even if a small volume fraction of nanometer-scale crystalline phase (which cannot be detected by X-ray diffraction and OM techniques) is included in the present alloys, it is believed that it would not have significant influence on soft magnetic properties. Thermal stability associated with glass transition, supercooled liquid and crystallization temperature was examined by differential scanning calorimetry (DSC) at a heating rate of $1.33 \mathrm{~K} / \mathrm{s}$. The melting $\left(T_{\mathrm{m}}\right)$ and liquidus $\left(T_{1}\right)$ temperatures were measured by differential thermal analysis (DTA) at heating and cooling rates of 0.33 and $0.033 \mathrm{~K} / \mathrm{s}$, respectively. Magnetic properties 
were measured with a vibrating sample magnetometer (VSM) and a B-H loop tracer under applied fields of $400 \mathrm{kA} / \mathrm{m}$ and $800 \mathrm{~A} / \mathrm{m}$, respectively. The Curie temperature was also determined by DSC. Density was measured by the Archimedian method using toluene solution.

\section{Results}

When we used the $\mathrm{Fe}_{75} \mathrm{~B}_{15} \mathrm{Si}_{10}$ ternary alloy, the amorphous alloy ribbon was produced but neither glass transition nor supercooled liquid region were observed. In addition, we could not produce any bulk amorphous alloy rods in the $\mathrm{Fe}-\mathrm{B}-\mathrm{Si}$ alloy by copper mould casting. These results are in agreement with previous data. ${ }^{21,22)}$ However, the addition of $\mathrm{Nb}$, which has a much larger atomic size ${ }^{23)}$ and negative heats of mixing ${ }^{24)}$ compared to Fe, B and Si enabled formation of bulk glassy alloy rods. Figure 1 shows the DSC curve of the 1 at $\% \mathrm{Nb}$-bearing alloy rod with a diameter of $0.5 \mathrm{~mm}$, together with the data of the melt-spun glassy ribbon. The DSC curve of the alloy rod indicates two endothermic peaks due to Curie temperature $\left(T_{\mathrm{c}}\right)$ and glass transition temperature $\left(T_{\mathrm{g}}\right)$ and three exothermic peaks due to crystallization, in agreement with the feature of the alloy ribbon. The $T_{\mathrm{g}}$ was determined by the intersection of the extrapolate from the baseline of DSC curve and the endothermic reaction curve due to glass transition. The $T_{\mathrm{c}}, T_{\mathrm{g}}$ and crystallization temperature $\left(T_{\mathrm{x}}\right)$ are $684 \mathrm{~K}, 815 \mathrm{~K}$ and $858 \mathrm{~K}$, respectively, and there is no appreciable difference in the thermal stability between the rod and ribbon samples. Considering the previous results that no glass transition is observed in the $\mathrm{Fe}_{75} \mathrm{~B}_{15} \mathrm{Si}_{10}$ alloy and no bulk glassy alloy is formed, ${ }^{22)}$ the addition of $\mathrm{Nb}$ is very ef-

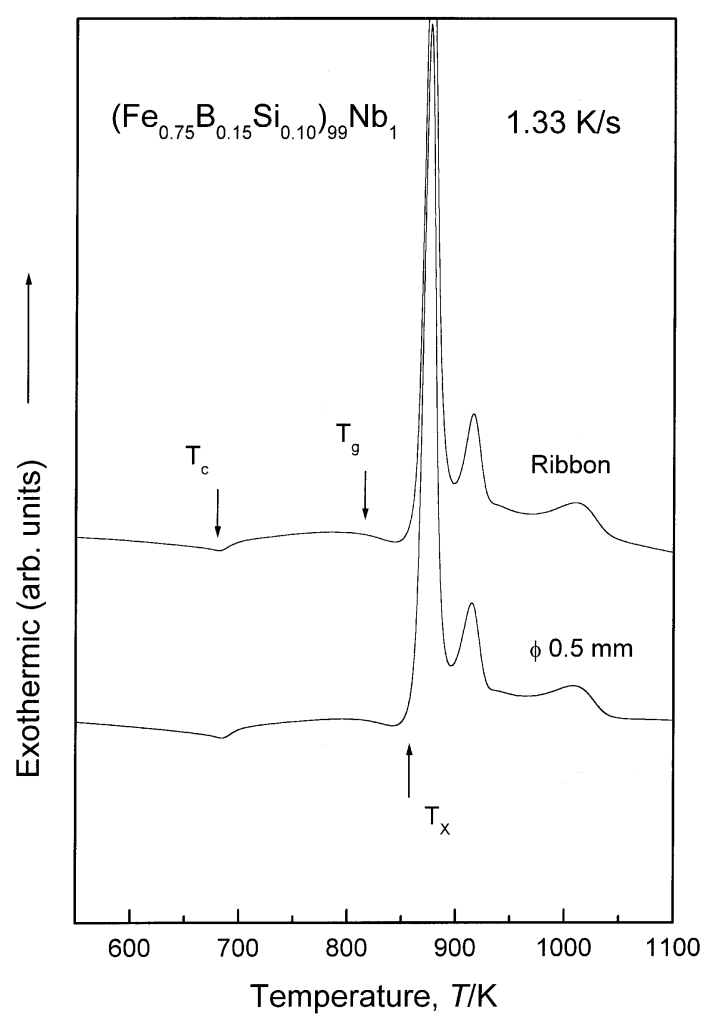

Fig. 1 DSC curve of a bulk glassy $\left(\mathrm{Fe}_{0.75} \mathrm{~B}_{0.15} \mathrm{Si}_{0.10}\right)_{99} \mathrm{Nb}_{1}$ alloy rod with a diameter of $0.5 \mathrm{~mm}$ produced by copper mould casting. The data of the melt-spun glassy alloy ribbon are also shown for comparison. fective in increasing glass-forming ability through an increase in stability of supercooled liquid against crystallization.

The maximum rod diameter for formation of a glassy phase increased with increasing $\mathrm{Nb}$ content, from $0.5 \mathrm{~mm}$ for the $1 \mathrm{at} \% \mathrm{Nb}$-bearing alloy, $1 \mathrm{~mm}$ for the $2 \mathrm{at} \% \mathrm{Nb}$-bearing alloy and $1.5 \mathrm{~mm}$ for the $4 \mathrm{at} \% \mathrm{Nb}$-bearing alloy. Figure 2 shows an optical micrograph of the transverse cross-section of the $4 \mathrm{at} \% \mathrm{Nb}$ alloy rod with a diameter of $1.5 \mathrm{~mm}$. Although some cavities are observed as small dark spots, no distinct crystalline contrast is seen over the whole crosssection, indicating the formation of a glassy single phase. We further confirmed that the thermal stability is independent of rod diameter. As examples, the DSC curves of the $\left(\mathrm{Fe}_{0.75} \mathrm{~B}_{0.15} \mathrm{Si}_{0.1}\right)_{96} \mathrm{Nb}_{4}$ alloy rods with diameters of $0.5,1.0$ and $1.5 \mathrm{~mm}$ are shown in Fig. 3, where the data of the meltspun alloy ribbon are also shown for comparison. It can be seen that the DSC curves of the alloy rods have features similar to the ribbon, and there is no appreciable difference in thermal stability with rod diameter. The $T_{\mathrm{c}}, T_{\mathrm{g}}$ and $T_{\mathrm{x}}$ are $593 \mathrm{~K}, 835 \mathrm{~K}$ and $885 \mathrm{~K}$, respectively. In comparison with the data for the $1 \mathrm{at} \% \mathrm{Nb}$-bearing alloy shown in Fig. 1, an increase in $\mathrm{Nb}$ content from 1 to 4 at $\%$ causes a decrease in $T_{\mathrm{c}}$ and an increase in $T_{\mathrm{g}}, T_{\mathrm{x}}$ and supercooled liquid region $\Delta T_{\mathrm{x}}\left(=T_{\mathrm{x}}-T_{\mathrm{g}}\right)$. We also measured the liquidus temperature $\left(T_{1}\right)$ with the aim of determining the reduced glass transition temperature $\left(T_{\mathrm{g}} / T_{1}\right)$ which has been regarded as one of the important parameters for evaluation of glass formation. As shown in Fig. 4, the sample was firstly melted at a heating rate of $0.33 \mathrm{~K} / \mathrm{s}$, followed by cooling of the sample at a much lower rate of $0.033 \mathrm{~K} / \mathrm{s}$, to keep a thermal equilibrium state. The freezing reaction of the alloys, except the 4 at $\% \mathrm{Nb}-$ bearing alloy, occurs through several stages as is evident from the cooling branches of the DTA curves. This indicates that these alloys deviate from eutectic composition. The cooling branch in the DTA curve has a single stage of freezing reaction only for the $4 \mathrm{at} \% \mathrm{Nb}$ alloy. The DTA data indicate that the eutectic point lies around $\left(\mathrm{Fe}_{0.75} \mathrm{~B}_{0.15} \mathrm{Si}_{0.1}\right)_{96} \mathrm{Nb}_{4}$ with $T_{1}$ of $1375 \mathrm{~K}$. The resulting $T_{\mathrm{g}} / T_{1}$ is measured as 0.56 for the $1 \mathrm{at} \% \mathrm{Nb}$-bearing alloy, 0.57 for the $2 \mathrm{at} \% \mathrm{Nb}$ alloy and 0.61 for the 4 at $\% \mathrm{Nb}$ alloy. The highest $T_{\mathrm{g}} / T_{1}$ value for the

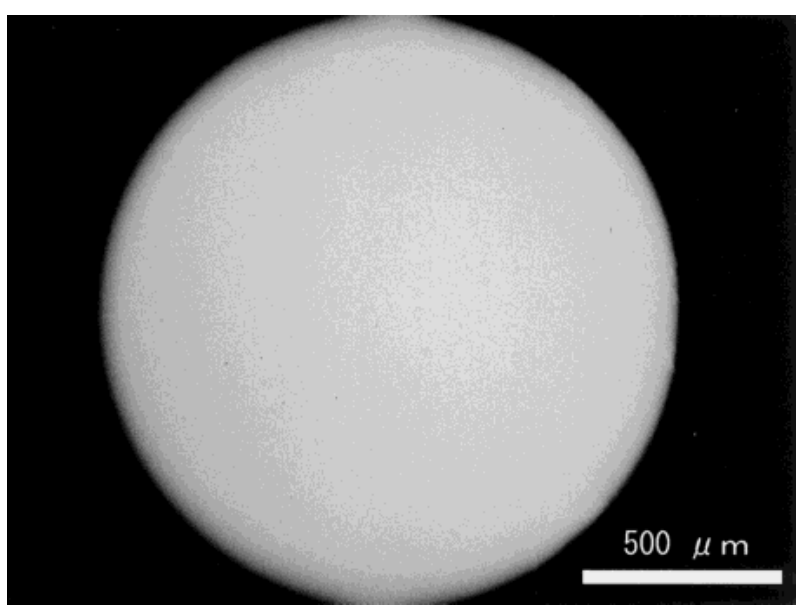

Fig. 2 Optical micrograph of a transverse cross-section of the bulk glassy $\left(\mathrm{Fe}_{0.75} \mathrm{~B}_{0.15} \mathrm{Si}_{0.1}\right)_{96} \mathrm{Nb}_{4}$ alloy rod with a diameter of $1.5 \mathrm{~mm}$ produced by copper mould casting. 


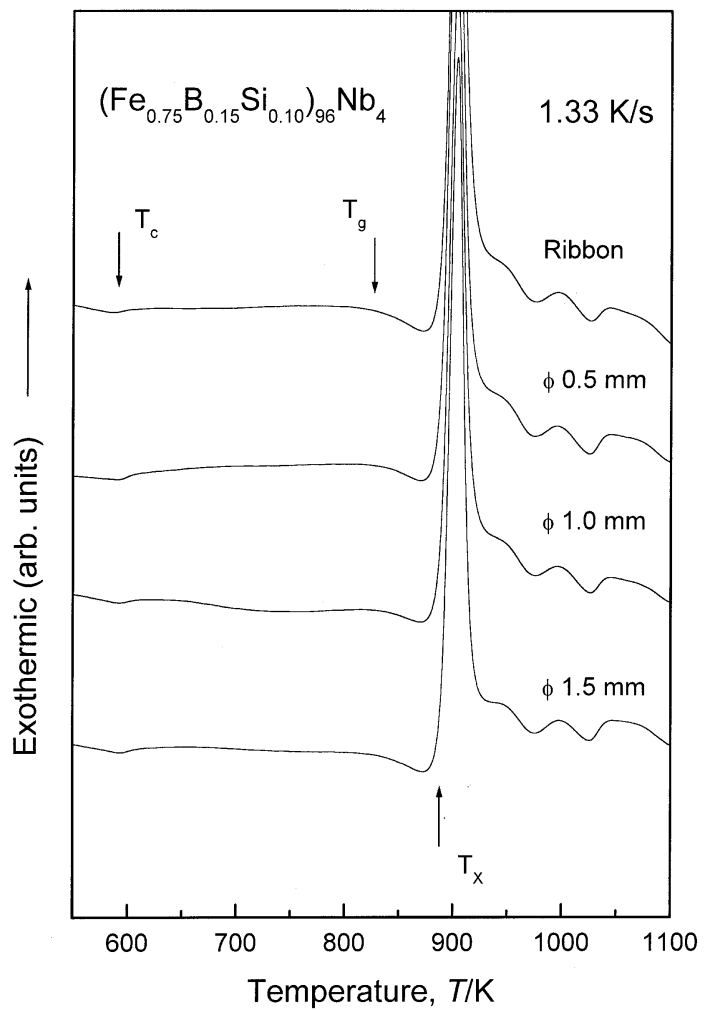

Fig. 3 DSC curves of bulk glassy $\left(\mathrm{Fe}_{0.75} \mathrm{~B}_{0.15} \mathrm{Si}_{0.10}\right){ }_{96} \mathrm{Nb}_{4}$ alloy rods with diameters of $0.5,1.0$ and $1.5 \mathrm{~mm}$ produced by copper mould casting. The data of the melt-spun glassy alloy ribbon are also shown for comparison.

$4 \mathrm{at} \% \mathrm{Nb}$ alloy indicates that the alloy has the highest glassforming ability, in agreement with the results described above and shown in Figs. 2 and 3. This also indicates that the addition of $\mathrm{Nb}$ is effective for an increase in the thermal stability of the supercooled liquid before crystallization as well as a decrease in liquidus temperature.

As is evident from the Curie point on the DSC curves shown in Figs. 1 and 3, the Fe-based glassy alloy rods possess ferromagnetic characteristics at room temperature. Table 1 summarizes magnetic properties of $T_{\mathrm{c}}$, saturation magnetization $\left(I_{\mathrm{s}}\right)$ and coercive force $\left(H_{\mathrm{c}}\right)$ of the Fe-based bulk glassy alloy rods. It is noticed that good soft magnetic properties, i.e., $T_{\mathrm{c}}$ of $634 \mathrm{~K}, I_{\mathrm{s}}$ of $1.51 \mathrm{~T}, H_{\mathrm{c}}$ of $3.7 \mathrm{~A} / \mathrm{m}$, are obtained for the bulk glassy $\left(\mathrm{Fe}_{0.775} \mathrm{~B}_{0.125} \mathrm{Si}_{0.10}\right)_{98} \mathrm{Nb}_{2}$ rod of $0.5 \mathrm{~mm}$ diameter. This is believed to be the first evidence for the synthesis of soft magnetic bulk glassy alloys with high $I_{\mathrm{s}}$ exceeding $1.5 \mathrm{~T}$. The good soft magnetic properties combined with high $I_{\mathrm{S}}$ and the simple alloy components are promising for the future development as a new soft magnetic bulk alloy.

\section{Discussion}

Here we discuss the reason for the effectiveness of $\mathrm{Nb}$ addition on the glass-forming ability of $\mathrm{Fe}-\mathrm{B}-\mathrm{Si}$ alloys. It has been previously reported that the maximum sample thickness of $\mathrm{Fe}-\mathrm{B}-\mathrm{Si}$ ternary amorphous alloys is about $270 \mu \mathrm{m}$ for a composition of $\mathrm{Fe}_{75} \mathrm{~B}_{15} \mathrm{Si}_{10}$ and that deviation of metalloid composition from this optimum value causes a significant decrease in the maximum sample thickness. ${ }^{22)}$ We have proposed three empirical rules ${ }^{4-6)}$ for alloy components leading to the formation of bulk glassy alloys through an extension of

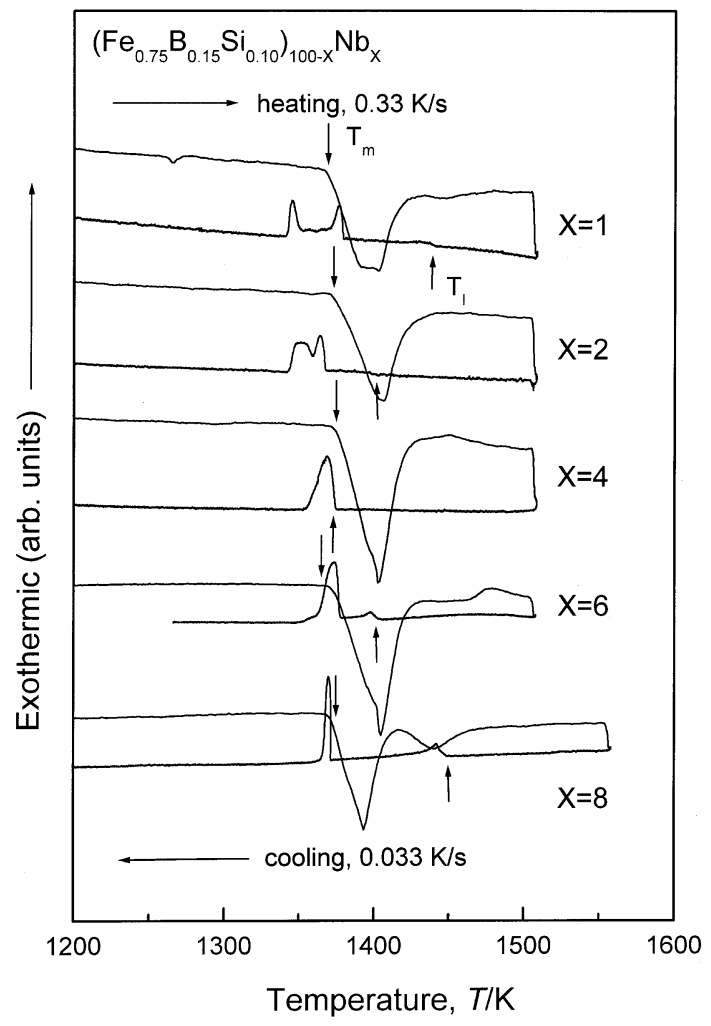

Fig. 4 DTA curves of pre-alloyed $\left(\mathrm{Fe}_{0.75} \mathrm{~B}_{0.15} \mathrm{Si}_{0.10}\right)_{100-x} \mathrm{Nb}_{x}(x=1,2$ and 4 at $\%$ ) alloys.

the supercooled liquid region. That is, all bulk glassy alloys in $\mathrm{Mg}-, \mathrm{Ln}-, \mathrm{Zr}-, \mathrm{Fe}-$, $\mathrm{Co}-, \mathrm{Ni}-$ and $\mathrm{Cu}-$ based systems must have multi-components consisting of more than three elements, significant atomic size mismatches above $12 \%$ among the three main elements, and negative heats of mixing between the main elements. ${ }^{4-6,10,11)}$ As is evident from the alloy components in Fe-based bulk glassy alloys shown in Section 1, the Fe-B-Si alloys can be interpreted to consist of only two element groups in the $\mathrm{Fe}-(\mathrm{B}, \mathrm{Si})$ system, and addition of the third group element is necessary for the satisfaction of the three component rules. This role is fulfilled by the addition of $\mathrm{Nb}$. The atomic size ratio is $15 \%$ for $\mathrm{Nb} / \mathrm{Fe}, 59 \%$ for $\mathrm{Nb} / \mathrm{B}$ and $22 \%$ for $\mathrm{Nb} / \mathrm{Si}^{2}{ }^{23)}$ In addition, all the heats of mixing for $\mathrm{Nb}-\mathrm{Fe}, \mathrm{Nb}-\mathrm{B}$ and $\mathrm{Nb}-\mathrm{Si}$ pairs are in the range of -9 to $-79 \mathrm{~kJ} / \mathrm{mol}^{24)}$ It has been previously reported that glassy alloys which conform to the three component rules can have a unique glassy structure with a higher degree of dense random packed atomic configurations, new local atomic configurations and long-range attractive interactions. ${ }^{4-6)}$ In the alloy liquid with these structural features, atomic mobility is reduced, leading to an increase in viscosity and/or $T_{\mathrm{g}}$ as well as a suppression of atomic rearrangement for the progress of crystallization reaction. It is thus presumed that the enhancement of the glass-forming ability by the addition of $\mathrm{Nb}$ to $\mathrm{Fe}-\mathrm{B}-\mathrm{Si}$ alloys is attributed to the above-described structural change in the structure. Further detailed study on the structure of the $\mathrm{Fe}-\mathrm{B}-\mathrm{Si}-\mathrm{Nb}$ alloys is expected to shed some light on the clarification of the mechanism for the remarkable effectiveness of $\mathrm{Nb}$ addition on glass-forming ability. 
Table 1 Magnetic properties and thermal stability of bulk glassy $\left(\mathrm{Fe}_{0.75} \mathrm{~B}_{0.15} \mathrm{Si}_{0.10}\right)_{100-x} \mathrm{Nb}_{x}(x=1,2$ and 4 at $\%)$ and $\left(\mathrm{Fe}_{0.775} \mathrm{~B}_{0.125} \mathrm{Si}_{0.10}\right)_{98} \mathrm{Nb}_{2}$ alloy rods.

\begin{tabular}{|c|c|c|c|c|c|c|c|}
\hline \multirow{2}{*}{ Alloy } & \multirow{2}{*}{$\begin{array}{c}\text { Maximum sample thickness } \\
t_{\max }(\mathrm{mm})\end{array}$} & \multicolumn{4}{|c|}{ Thermal stability } & \multicolumn{2}{|c|}{ Soft magnetic properties } \\
\hline & & $T_{\mathrm{c}}(\mathrm{K})$ & $T_{\mathrm{g}}(\mathrm{K})$ & $\Delta T_{\mathrm{X}}(\mathrm{K})$ & $T_{\mathrm{g}} / T_{\mathrm{l}}$ & $B_{\mathrm{S}}(\mathrm{T})$ & $H_{\mathrm{c}}(\mathrm{A} / \mathrm{m})$ \\
\hline$\left(\mathrm{Fe}_{0.75} \mathrm{~B}_{0.15} \mathrm{Si}_{0.10}\right)_{99} \mathrm{Nb}_{1}$ & 0.5 & 684 & 815 & 43 & 0.56 & 1.50 & 3.7 \\
\hline$\left(\mathrm{Fe}_{0.75} \mathrm{~B}_{0.15} \mathrm{Si}_{0.10}\right)_{98} \mathrm{Nb}_{2}$ & 1.0 & 650 & 812 & 58 & 0.57 & 1.49 & 3.5 \\
\hline$\left(\mathrm{Fe}_{0.75} \mathrm{~B}_{0.15} \mathrm{Si}_{0.10}\right)_{96} \mathrm{Nb}_{4}$ & 1.5 & 593 & 835 & 50 & 0.61 & 1.47 & 2.9 \\
\hline$\left(\mathrm{Fe}_{0.775} \mathrm{~B}_{0.125} \mathrm{Si}_{0.10}\right)_{98} \mathrm{Nb}_{2}$ & 0.5 & 634 & 760 & - & 0.54 & 1.51 & 3.7 \\
\hline
\end{tabular}

\section{Summary}

We have examined the effect of $\mathrm{Nb}$ addition on the glassforming ability of $\mathrm{Fe}_{75} \mathrm{~B}_{15} \mathrm{Si}_{10}$ alloy with the aim of synthesizing a new bulk glassy $\mathrm{Fe}-\mathrm{B}-\mathrm{Si}-\mathrm{Nb}$ alloy by use of the three component rules for achievement of bulk glass formation and stabilization of supercooled liquid. The results obtained are summarized as follows:

(1) Bulk glassy alloy rods were formed by the addition of $\mathrm{Nb}$; the maximum rod diameter was $0.5 \mathrm{~mm}$ at $1 \mathrm{at} \% \mathrm{Nb}$, $1.0 \mathrm{~mm}$ at 2 at $\% \mathrm{Nb}$ and $1.5 \mathrm{~mm}$ at 4 at $\% \mathrm{Nb}$.

(2) No glass transition was observed at $0 \mathrm{at} \% \mathrm{Nb}$. The addition of $\mathrm{Nb}$ caused the appearance of $T_{\mathrm{g}}$. The $T_{\mathrm{g}}$ and $T_{\mathrm{x}}$ are $815 \mathrm{~K}$ and $858 \mathrm{~K}$, respectively, for the $1 \mathrm{at} \% \mathrm{Nb}$ alloy rod, $812 \mathrm{~K}$ and $870 \mathrm{~K}$, respectively, for the $2 \mathrm{at} \% \mathrm{Nb}$ alloy and $835 \mathrm{~K}$ and $885 \mathrm{~K}$, respectively, for the 4 at $\% \mathrm{Nb}$ alloy.

(3) The $T_{1}$ was measured as $1440 \mathrm{~K}$ at 1 at $\% \mathrm{Nb}, 1415 \mathrm{~K}$ at 2 at $\% \mathrm{Nb}$ and $1375 \mathrm{~K}$ at $4 \mathrm{at} \% \mathrm{Nb}$ and the resulting reduced glass transition temperature $\left(T_{\mathrm{g}} / T_{1}\right)$ was evaluated as 0.56 at 1 at $\% \mathrm{Nb}, 0.57$ at 2 at $\% \mathrm{Nb}$ and 0.61 at 4 at $\% \mathrm{Nb}$. The stability of supercooled liquid against crystallization as well as the glass-forming ability increases distinctly with increasing $\mathrm{Nb}$ content.

(4) The Fe-based bulk glassy alloy rods containing $\mathrm{Nb}$ contents up to 4 at $\%$ exhibit ferromagnetic characteristics, and the $T_{\mathrm{c}}, I_{\mathrm{s}}$ and $H_{\mathrm{c}}$ are 593 to $684 \mathrm{~K}, 1.47$ to $1.51 \mathrm{~T}$ and 2.9 to $3.7 \mathrm{~A} / \mathrm{m}$, respectively, at room temperature. The simultaneous achievement of good soft magnetic properties with high $I_{\mathrm{S}}$ of $1.5 \mathrm{~T}$ and bulk glassy alloys in the simple $\mathrm{Fe}-\mathrm{B}-\mathrm{Si}-\mathrm{Nb}$ system is important for future development of Fe-based soft magnetic bulk glassy alloys.

\section{REFERENCES}

1) A. Inoue, K. Ohtera, K. Kita and T. Masumoto: Jpn. J. Appl. Phys. 27 (1988) L2248-L2251.
2) A. Inoue, T. Zhang and T. Masumoto: Mater. Trans., JIM 30 (1989) 965-972.

3) A. Inoue, T. Zhang and T. Masumoto: Mater. Trans., JIM 31 (1990) 177-183.

4) A. Inoue: Mater. Trans., JIM 36 (1995) 866-875.

5) A. Inoue: Bulk Amorphous Alloys, (Trans Tech Publications, Zurich, 1998) pp. 1-33.

6) A. Inoue: Acta Mater. 48 (2000) 279-306.

7) Supercooled Liquid, Bulk Glassy and Nanocrystalline States of Alloys, ed. by A. Inoue, A. R. Yavari, W. L. Johnsson and R. H. Dauskardt, pp. L12.13.1-L12.13.6.

8) A. Inoue and G. S. Gook: Mater. Trans., JIM 36 (1995) 1180-1183.

9) B. L. Shen, J. Koshiba, A. Inoue, H. M. Kimura and T. Mizushima: Mater. Trans. 42 (2001) 2136-2139.

10) X. M. Wang, I. Yoshii, A. Inoue, Y. H. Kim and I. B. Kim: Mater. Trans., JIM 40 (1999) 1130-1136.

11) A. Inoue, W. Zhang, T. Zhang and K. Kurosaka: Acta Mater. 49 (2001) 2645-2652.

12) A. Inoue, N. Nishiyama and T. Matsuda: Mater. Trans., JIM 37 (1996) 181-184.

13) A. Inoue, M. Nishiyama and H. M. Kimura: Mater. Trans., JIM 38 (1997) 179-183.

14) A. Inoue and G. S. Gook: Mater. Trans., JIM 37 (1996) 32-38.

15) T. D. Shen and R. B. Schwarz: Appl. Phys. Lett. 75 (1999) 49-51.

16) B. L. Shen, H. M. Kimura, A. Inoue and T. Mizushima: Mater. Trans., JIM 41 (2000) 1675-1678.

17) B. L. Shen, H. Koshiba, T. Mizushima and A. Inoue: Mater. Trans., JIM 41 (2000) 873-876.

18) A. Inoue, T.Zhang, H. Koshiba and A. Makino: J. Appl. Phys. 83 (1998) 6326-6328.

19) A. Inoue, T. Zhang and A. Takeuchi: Appl. Phys. Lett. 71 (1997) 464466.

20) S. Pang, T. Zhang, K. Asami and A. Inoue: Mater. Trans., JIM 42 (2001) 376-379.

21) M. Mitera, M. Naka, T. Masumoto, N. Kazama and H. Watanabe: Phys. Status. Solidi. (a) 49 (1978) K163-K166.

22) M. Hagiwara, A. Inoue and T. Masumoto: Sci. Rep. Res. Inst. Tohoku Univ. A29 (1981) 351-358.

23) Metals Databook, ed. by Japan Inst. Metals, Maruzen, Tokyo (1983) p. 8.

24) F. R. Niessen: Cohesion in Metals, (Elsevier Science Publishers, B.V., Amsterdam, 1988) pp. 394-401. 